\title{
Taking the hex off transgenic plant exports
}

\section{Russ Hoyle}

Last month the first shipment of Monsanto's genetically engineered Roundup Ready soybeans was escorted into Hamburg harbor by a Greenpeace barge and two inflatable dinghies manned by protesters. Using slide projectors, the environmentalists reportedly emblazoned slogans on the side of the offending ship that read "Genetic Experiment-Don't Buy It!" "We're Not Your Guinea Pigs." Even Jeremy Rifkin, the self-proclaimed bête noire of biotechnology, flew to Hamburg for the occasion. "This global boycott will not go away," he trumpeted. Not long ago, Rifkin also promised to kill bovine growth hormone, which last month reportedly turned its first profit. Nonetheless, the outcry-and the 120,000 signatures Greenpeace collected to endorse the sea-going protest-rattled food industry executives in Europe, where Britain's mad cow problems and stiffbacked European regulatory officials have helped create a fullblown consumer boycott of genetically engineered American agricultural products.

By attacking US products and regulatory standards as insufficient for European marketplaces, the antibiotechnology forces have managed again to plant questions in the minds of consumers and politicians about the efficacy and safety of recombinant DNA technology itself, framing rational-sounding arguments in favor of placing severe limitations on genetically modified products, not because they are dangerous, but because they are genetically modified.

This is déjà vu all over again. There is, of course, no credible scientific evidence to back up such a premise. Indeed, long-accepted scientific studies, most notably from the National Academy of Sciences (Washington, DC) and the US National Research Council (Washington, DC), have concluded just the opposite: That there is nothing inherently dangerous about the process of genetic engineering. That is why, with products from bovine somatotropin to herbicidal soybeans, US law does not require labeling. Even biotechnology critics Margaret Mellon and Jane Rissler of the Union of Concerned Scientists (Washington, DC), the environmentalist doyennes of truly draconian regulation of transgenic plants, now concede "There are no properties or risks attached to an organism just because it has been engineered."

If stricter regulation of transgenic plants is what European consumers and food industry officials want, Mellon and Rissler have laid out the blueprint for them in their book, The Ecological Risks of Engineered Crops, published last year by the Union of Concerned Scientists
(London) and the Massachusetts Institute of Technology Press (Cambridge, MA), Mellon and Rissler recommend a comprehensive regulatory protocol that would rationalize and codify the current patchwork of US regulations on genetically engineered crops.

To accomplish this, the authors posit a publicly funded research agency with a mandate for environmental protection that would assess the risks of transgenic plants. Among other things, they propose that the United Nations (New York) develop international biosafety standards that would protect habitats and croplands, especially in developing countries, against the presumed risks posed by genetically engineered crops - a process that is already underway under the aegis of the Biodiversity Treaty. In the end, their analysis is based on their observation that "The longterm impacts of transgenic plants in the environment are unpredictable and difficult, if not impossible, to predict at the current level of scientific understanding."

In this, they are absolutely correct. Take the two genetically engineered US products that have been the source of European anxieties this fall. Ciba-Geigy's genetically modified Maximizer hybrid corn, which was codeveloped by Mycogen (San Diego, CA), contains a gene from a common soil bacteria, Bacillus thuringiensis, that destroys the digestive system of and kills the European corn borer, a pest that is estimated to lay waste to $\$ 1$ billion worth of corn a year in the US. Scientists inside and outside of the biotechnology industry know that in time the product will create a tougher, resistant corn borer. But they don't know when, or exactly how to avoid it. With assiduous crop management techniques, some believe the window for such $B t$ products is less than a decade. Scientists don't know.

In addition, Ciba-Geigy's Maximizer contains a marker gene that confers resistance to ampicillin. Could DNA for ampicillin resistance spread to other bacteria or become encoded within an animal that ingests it? The weight of scientific opinion is that the odds are so long that the risk is negligible-indeed, the possibility of ampicillin-resistance gene being expressed in the natural environment is greater. But the fact is, scientists don't actually know.

If anything, even more perplexing questions swirl around the Monsanto's Roundup Ready soybeans-which are genetically designed to resist glyphosate, the active ingredient of Monsanto's own popular Roundup herbicide, which is applied directly to crops. Glyphosate is reportedly nontoxic to animals and quickly destroyed by microorganisms.
Outside studies confirm that it can be deployed in low doses, in some cases a matter of grams per acre rather than pounds per acre for highly toxic chemical herbicides such as atrazine. But there is as yet no comprehensive scientific literature proving that such low-dose herbicides are environmentally friendly or safe for animal and human consumption.

Worse, Monsanto has earned a reputation among biotechnology critics and farmers alike for greedy profiteering by using genetic engineering to create one product to enhance the sales of another-Robert Shapiro, Monsanto's chairman and CEO, admits to pumping money into Roundup "as fast as we know how." Roundup Ready soybeans too will almost certainly create tougher, more resistant weeds. But again, the scientific evidence is not in, and Monsanto scientists can only try to stay ahead of the resistance-development curve by "stacking" genes in plant cells.

The problems Monsanto and Ciba-Geigy are facing in Europe are essentially political, not scientific. They do, however, boil down to the fact that the production of potentially useful and profitable genetically engineered products has outstripped the industry's understanding of them. Scientists cannot accurately predict processes like genetic transmission or the development of resistance in plants or insects. That uncertainty gives the highly opportunistic enemies of biotechnology like Greenpeace and Jeremy Rifkin all they need to sow fear and doubt among European consumers.

But it would be a mistake for the food industry in either the US or Europe to believe it must subject these products to stricter regulatory review as food additives under the current statutes to appease consumers. It would be equally unproductive to undertake a broad-based rethinking of current US regulations, however patchwork and imperfect they may be, to arrive at tougher international standards.

European and US biotechnology interests should stay the course. Press ahead to harmonize regulatory regimes that emphasize both consumer protection and commercialization of innovative products. Acknowledge the limits of scientific knowledge and continue to throw its resources into understanding the mysteries of genetic transmission, natural resistance to pests and weeds and the products that are being developed through recombinant DNA technology to achieve those ends. And lastly, give the marketplace time to sort out the good products from those that are merely profitable. 